\title{
DOKUMENTUM
}

DOI: http://dx.doi.org/10.17355/rkkpt.v25i3.185

\section{Ukrajna 2017. szeptember 5-én kelt 2145-VIII. sz. törvénye „Az oktatásról”}

\section{Hatályba lépett 2017. szeptember 28-án. ${ }^{1}$}

Az oktatás az egyén intellektuális, szellemi, fizikai és kulturális fejlődésének, sikeres szocializációjának, gazdasági életrevalóságának alapja, a közös értékek és kultúra, valamint az állam által egyesített társadalom fejlödésének biztosítéka.

Az oktatás célja az ember, mint személyiség és a társadalom legértékesebb alkotórésze sokoldalú fejlesztése, tehetségének, intellektuális, alkotó és fizikai képességeinek kibontakoztatása, értékrend és a sikeres önmegvalósításhoz szükséges kompetenciák kialakítása, felelös állampolgárok nevelése, akik képesek a tudatos választásra, tevékenységükkel a többi embert és a társadalmat szolgálni, s ezzel együtt az Ukrán nép ${ }^{2}$ intellektuális, gazdasági, alkotó, kulturális potenciálját gazdagítani, az állampolgárok iskolázottsági szintjének emelése Ukrajna töretlen fejlődésének és európai orientációjának biztosítása érdekében.

Ez a Törvény $^{3}$ szabályozza azokat a feltételeket, amelyek az embereknek az oktatáshoz füződő alkotmányos joga érvényesítését,

\footnotetext{
${ }^{1}$ Az ukrajnai törvények a hivatalos közlönyben való megjelenés utáni napon lépnek hatályba. Az új oktatási törvényt a Holos Ukrajiny (Голос України) 2017. szeptember 27-i, 178-179. száma hozta le. A törvény hivatalos, eredeti szövegét lásd a törvénytárban: http://zakon2.rada.gov.ua/laws/show/214519/page (2017-09-28) A törvényböl itt közölt részleteket saját, nem hivatalos fordításban adjuk közre. Az eredeti szövegben nincsenek jegyzetek, az itt olvasható kommentárokat a fordítók készítették a szöveg értelmezésének megkönnyítésére. Fordította: Fedinec Csilla és Csernicskó István.

${ }^{2}$ Az eredeti szövegben szerepel így nagy betüvel, noha az ukrán helyesírás szerint is kis betűvel írandó. A dokumentum nyelvezete (filológiai szempontból is) meglehetően nehézkes.

3 Amikor a „Törvény” szó nagy betüvel van írva, akkor konkrétan a jelen törvényre, amikor kis betűvel szerepel, akkor pedig a törvényi háttérre általában utal a szöveg.
}

REGIO 25. évf. (2017) 3. szám 260-277. 
az ezen jogok érvényesítésében részt vevő természetes és jogi személyek jogait és kötelességeit befolyásolják, valamint meghatározza az állami intézmények és a helyi önkormányzatok szerepét az oktatás folyamatában.

\section{FEJEZET}

\section{ÁLTALÁNOS RENDELKEZÉSEK}

\section{1. cikk. Alapfogalmak és definíciójuk}

1. Jelen Törvényben az egyes fogalmak az alábbi értelemben használatosak:

1) autonómia - az oktatási tevékenység alanyának joga az önkormányzathoz, ami az önállóságban, a függetlenségben és a felelösségben nyilvánul meg az akadémiai (oktatási), szervezési, pénzügyi, személyi és egyéb ügyek tekintetében, melyek a törvény által meghatározott rendben és keretek között valósulnak meg;

2) akadémiai szabadság - az oktatási folyamat résztvevőinek önállósága és függetlensége a pedagógiai, tudományos-oktatási, tudományos és/vagy innovációs tevékenység során, melyhez biztosított a szólás, a gondolatok és az alkotómunka szabadsága, az ismeretek és az információk terjesztése, a tudományos kutatások eredményeinek szabad közlése és felhasználása a törvény által meghatározott korlátozások figyelembevételével;

3) ingyenes oktatás - az oktatás, amelyhez az adott személy az állami és/vagy a helyi költségvetések terhére jut hozzá a törvényeknek megfelelően;

4) oktatási tevékenység - az a tevékenység, amely az oktatásban résztvevő tudásának, egyéb kompetenciáinak, világnézetének alakítására, intellektuális és alkotó képességeinek, érzelmi-akarati és/vagy fizikai tulajdonságainak fejlesztésére irányul (előadások, szemináriumok, tréningek, tanfolyamok, mesterkurzusok, online kommunikáció stb. keretében), s amelyet pedagógus (tudós-tanár), vállalkozó ${ }^{4}$ (azon személyek kivételével, akiket a törvény a pedagógiai tevé-

\footnotetext{
${ }^{4}$ Itt és a továbbiakban: adófizető magánvállalkozó, pl. tudós, író, művész, oktató, könyvelő, misszionárius, magán orvos, ügyvéd, közjegyző stb. (ukr. самозайнята особа).
}

REGIO 25. évf. (2017) 3. szám 260-277. 
kenységből kizár) vagy más természetes személy lát el munkaügyi vagy polgári szerződés keretében;

5) digitális tankönyv (olvasókönyv) - webes oktatási kiadvány rendszerezett tananyaggal, amely megfelel a tantervnek, különböző formátumú tartalmakkal, interaktív hozzáféréssel;

6) oktatási intézmény - önálló jogi személyiségü nyilvános vagy magán intézmény, melynek alapvető tevékenységi formája az oktatás;

7) oktatási intézmény alapítója - az állam nevében eljáró állami intézmény, egy adott közösség által létrehozott testület, természetes és/vagy jogi személyiség, akinek a döntése alapján és finanszírozásával oktatási intézményt alapítanak, vagy más olyan személyiség, amely a törvény erejénél fogva tett szert alapítói jogokra és kötelességekre;

8) az oktatás alanyai - neveltek, tanulók, diákok, kadétok, hallgatók, gyakornokok, aspiránsok (posztgraduális tanulmányokat folytatók), doktoranduszok, ${ }^{6}$ egyéb személyek, akik bármilyen formában oktatásban részesülnek;

9) magántanuló - egyénileg megválasztott tanulási útvonal az oktatás típusának, formájának és ütemének, valamint az oktatási intézmény és az általa kínált képzési program, tantárgyak és azok mélységének, az oktatási módszerek és eszközök szabad megválasztása az adott személy képességeinek, érdekeinek, szükségleteinek, motivációjának, lehetőségeinek és tapasztalatainak figyelembe vételével;

10) egyéni fejlesztési program - az a dokumentum, amelyik biztosítja a sajátos oktatási igényü személyek egyéni oktatását, megállapítja a szükséges pszichológiai-pedagógiai, fejlesztő szükségletek/szolgáltatások körét a gyermekek fejlesztése érdekében, melyet szakemberek csoportja dolgoz ki a gyermek szüleinek feltétlen bevonásával az oktatás konkrét stratégiáinak és megközelítési módjainak meghatározása érdekében;

5 Territoriális (regionális) közösség - az önkormányzatokról szóló 1996. évi törvény 2016-os módosítása során alkotott fogalom, jelentése: önálló közigazgatási státussal rendelkező falu, nagyközség vagy város közössége; több település közössége, melyeknek közös a közigazgatási központjuk.

${ }^{6}$ Ukrajnában a posztgraduális képzés két formában létezik: a szovjet időkből örökölt aspiránsképzés, annak megfelelő tudományos fokozatokkal (kandidátus, nagydoktor), illetve a bolognai rendszerü doktoranduszképzés, szintén a megfelelő tudományos fokozat megszerzésének lehetőségével $(\mathrm{PhD})$.

REGIO 25. évf. (2017) 3. szám 260-277. 
11) egyéni tanterv - az a dokumentum, amely meghatározza az oktatási programban meghatározott kompetenciák megszerzésének sorrendiségét, formáját és ütemét az oktatásban részesülő személy által, egyéni fejlesztési programjának megfelelően, és amelyet az oktatási intézmény dolgoz ki az oktatásban részesülővel együttmüködésben megfelelö anyagi fedezet megléte esetén;

12) inkluzív oktatás - az állam által szavatolt oktatási szolgáltatások rendszere, amelynek alapelvei a diszkrimináció tilalma, az ember sokszínűségének elismerése, minden alany hatékony bevonása és bekapcsolása az oktatási folyamatba;

13) inkluzív oktatási környezet - azon feltételek, eljárások és eszközök összessége, melyek biztosítják a közösségi oktatás, nevelés és fejlesztés feltételeit az oktatás alanyai számára szükségleteik és lehetőségeik figyelembe vételével;

14) minősítés - a felhatalmazott jogalany által elismert és megfelelö dokumentummal igazolt standard kompetenciahalmaz (az oktatás végeredménye);

15) kompetencia - tudás, készségek, képességek, gondolkodásmód, szemlélet, értékek, és egyéb személyes tulajdonságok dinamikus kombinációja, amely meghatározza az adott személy szocializációs képességét, munkavállalási és/vagy továbbtanulási alkalmasságát;

16) oktatási folyamat - tudományos-módszertani és pedagógiai intézkedések rendszere, amelyek célja a személyiség fejlesztése a megfelelő kompetenciák kialakítása és felhasználása által;

17) oktatási tevékenység - az oktatási tevékenység szubjektumának/ tevékenysége, amely az oktatási folyamat megszervezésére, biztosítására és megvalósítására irányul a formális és/vagy informális oktatásban;

18) oktatási szolgáltatás - a törvények, az oktatási tevékenység szubjektumának oktatási programja és/vagy szerződéses tevékenysége által meghatározott cselekvéssorozat, amely meghatározott értéket képvisel és arra irányul, hogy az oktatásban részesülő a tanulási folyamat során elérje a kívánt eredményt;

19) oktatási program - az oktatás összetevőinek (tantárgyak, specializált területek, egyéni feladatok, ellenőrző lépések stb.) egységes rendszere, amelyet az oktatás meghatározott eredményének elérése érdekében terveztek és szerveztek meg; 
20) sajátos nevelésủ igényű személy - az a személy, aki az oktatási folyamat során állandó vagy ideiglenes korrepetálásra szorul az oktatáshoz füződő joga érvényesítése érdekében;

21) pedagógiai tevékenység - a pedagógus (tudományos-pedagógiai munkatárs) vagy vállalkozó intellektuális, alkotó tevékenysége a formális és/vagy informális oktatásban, amely az oktatásra, nevelésre, a személyiség müveltségi, állampolgári és/vagy szakmai kompetenciáinak fejlesztésére irányul;

22) az oktatás eredménye - tudás, képesség, hozzáértés, gondolkodásmód, szemlélet, értékek, egyéb személyes tulajdonságok, amelyek az oktatás, nevelés és fejlesztés folyamatában alakultak ki, s amelyeket be lehet azonosítani, meg lehet tervezni, értékelni és mérni és amelyeket az adott személy meg tud mutatni az oktatási folyamat egészének vagy egyes összetevőinek lezárulása után;

23) az oktatás szintje - befejezett oktatási fokozat, amelyet adott nehézségi fokú oktatási program, kompetenciaegyüttes jellemez, melyeket szabály szerint az oktatási standardok és a Nemzeti Képesítési Keretrendszer ${ }^{7}$ határoznak meg;

24) ésszerü alkalmazás - konkrét esetben, amennyiben szükséges, olyan módosítások és kiigazítások bevezetése, amelyek lehetővé teszik a sajátos nevelési igényü személyeknek az oktatáshoz való hozzáférés alkotmányos jogának az egyenlő bánásmód elve alapján történő érvényesítését;

25) oktatási rendszer - az oktatás, az oktatás szintjei és fokozatai, a képesítés, az oktatási programok, az oktatási standardok, hivatalos müködési feltételek, oktatási intézmények és az oktatási tevékenység egyéb szubjektumai, az oktatási folyamat résztvevői, az oktatás felügyeleti szervei, a rendszerek müködését meghatározó jogszabályok összessége;

26) ágazati jogszabályok - Ukrajna törvényei „Az iskoláskor előtti nevelésről”, ${ }^{8}$, ,Az általános iskolai oktatásról”, , „Az iskolán kívüli oktatásról”, ${ }^{10}$ "A szakképzésről”, ${ }^{11}$ „A felsőoktatásról”, ${ }^{12}$

72011 óta érvényben levő minősítése rendszer (ukr. Національна рамка кваліфікацій).

http://mon.gov.ua/activity/education/naczionalna-ramka-kvalifikaczij/ (2017-0928)

${ }^{8}$ http://zakon2.rada.gov.ua/laws/show/2628-14 (2017-09-28)

${ }^{9}$ http://zakon2.rada.gov.ua/laws/show/651-14 (2017-09-28)

${ }^{10} \mathrm{http}: / /$ zakon2.rada.gov.ua/laws/show/1841-14 (2017-09-28)

REGIO 25. évf. (2017) 3. szám 260-277. 
27) az oktatási tevékenység szubjektuma - természetes vagy jogi személy (oktatási intézmény, vállalat, intézet, szervezet), amelyik oktatási tevékenységet folytat;

28) univerzális feltételek az oktatásban - tárgyak, környezet, oktatási programok és szolgáltatások olyan külső formai jegyekkel való ellátása, melyek biztosítják teljes körü használhatóságukat minden személy által külön alkalmazási feltételek vagy speciális eszközök nélkül;

29) az oktatás minősége - az oktatás eredményének megfelelése a jogszabályi környezet által támasztott követelményeknek, a vonatkozó oktatási standardoknak és/vagy az oktatási szolgáltatás nyújtására kötött szerződésnek;

30) az oktatási tevékenység minősége - az oktatási folyamat szervezettségének, az oktatási folyamat biztosításának és megvalósításának szintje, ami lehetővé teszi, hogy az érintett személyek minőségi oktatásban részesüljenek és az megfeleljen a jogszabályi követelményeknek és/vagy az oktatási szolgáltatás nyújtására kötött szerződésnek.

2. E törvény ${ }^{13}$ és az egyéb a szülökre vonatkozó törvények az oktatásban részt vevők egyéb törvényes képviselöire is kiterjednek. A szülők, az egyéb törvényes képviselök eleget tesznek e Törvény és a kiskorúakra, valamint a cselekvésükben korlátozott személyekre vonatkozó törvények elöírásainak.

\section{2. cikk. Az ukrajnai oktatásra vonatkozó jogszabályok}

1. Az ukrajnai oktatásra vonatkozó jogalkotás Ukrajna Alkotmányán ${ }^{14}$ alapszik, s összetevői a jelen Törvény, az ágazati törvények, az egyéb az oktatás és a tudomány tárgykörébe tartozó jogszabályok, valamint az Ukrajna által a törvényi elöírásoknak megfelelően megkötött nemzetközi szerződések.

2. Az alárendelt jogszabályok nem szükíthetik az oktatáshoz füződő alkotmányos jog tartalmát és kereteit, az oktatási tevékenység szub-

${ }^{11}$ http://zakon2.rada.gov.ua/laws/show/103/98-\%D0\%B2\%D1\%80 (2017-09-28)

$12 \mathrm{http}: / / z a k o n 2 . r a d a . g o v . u a / l a w s / s h o w / 1556-18$ (2017-09-28)

$13 \mathrm{Az}$ eredeti szövegben kis betűvel van írva a „törvény” szó, bár itt nyilvánvalóan jelen törvényröl van szó.

14 http://zakon2.rada.gov.ua/laws/show/254\%D0\%BA/96-\%D0\%B2\%D1\%80 (2017-09-28)

REGIO 25. évf. (2017) 3. szám 260-277. 
jektumai törvényben meghatározott autonómiáját, valamint az oktatási folyamat résztvevőinek tudományos szabadságát.

A levelek, utasítások, módszertani javaslatok, a végrehajtó hatalom egyéb dokumentumai, kivéve az Ukrajna Igazságügyi Minisztériuma által bejegyzett rendeleteket, és azon dokumentumokat, amelyek az adott intézmény belső müködését szabályozzák, nem tekinthetők jogi aktusoknak és nem állapíthatnak meg jogi normákat.

3. Az oktatási tevékenység szubjektumának jogában áll önállóan döntést hozni bármely kérdésben, amely autonóm hatáskörébe tartozik, s amely hatáskört jelen Törvény, a speciális törvények és/vagy alapító dokumentumok határoznak meg többek között az jogszabályokban nem szabályozott kérdésekben.

\section{3. cikk. Az oktatáshoz való jog}

1. Mindenkinek joga van a minőségi és elérhető oktatáshoz. Az oktatáshoz füződő jog magában foglalja az élethosszig tanulás lehetőségét, az oktatáshoz való hozzáférés jogát, az ingyenes oktatáshoz való hozzáférés jogát az Alkotmány és Ukrajna törvényeiben meghatározott esetekben és rendben.

2. Ukrajna megteremti annak a lehetőségét, hogy mindenki egyenlő feltételekkel jusson hozzá az oktatáshoz. Senkit nem lehet korlátozni az oktatáshoz füződő jogában. Az oktatáshoz füződő jogot életkortól, nemtől, fajtól, egészségi állapottól, rokkantságtól, állampolgárságtól, nemzetiségtől, politikai, vallási és egyéb meggyőződéstől, bőrszíntől, lakhelytől, a beszélt nyelvtől, ${ }^{15}$ a származástól, a szociális és vagyoni helyzettől, a büntetett-büntetlen előélettől, valamint egyéb körülményektől és megkülönböztető jegyektől függetlenül kell biztosítani.

3. Az adott személy az oktatáshoz való jogát a különböző szintü, formájú és típusú oktatási intézmények elvégzésével tudja érvényesíteni, többek között hozzáfér az iskoláskor elötti intézményekhez, érettségihez, iskolán kívüli oktatási formákhoz, alapfokú szakmai, felsőfokú szakmai végzettséget adó intézményekhez, felsőoktatáshoz, a felnőttképzési rendszerhez.

4. Mindenkinek joga van hozzáférni a nyilvános oktatási, tudományos és információs forrásokhoz, többek között az internethez, a

${ }^{15} U k r$. мова спілкування; szó szerint: kommunikációs nyelv.

REGIO 25. évf. (2017) 3. szám 260-277. 
web-tankönyvekhez és egyéb multimédiás oktatási anyagokhoz a törvények által meghatározott rendben.

5. Az állam szociális védelemben részesíti azokat a tanulókat, akikről a jogszabályok ilyen értelemben rendelkeznek, valamint egyenlö hozzáférést biztosít az oktatáshoz a lakosság szociálisan legsérülékenyebb tagjainak.

6. Az állam biztosítja az oktatáshoz való hozzáférést a sajátos nevelési igényü személyeknek, figyelembe véve egyéni szükségleteiket, lehetőségeiket, képességeiket és érdekeiket, valamint biztosítja azoknak a tényezőknek a feltárását és felszámolását, amelyek sértik az oktatáshoz való egyenlö hozzáférés jogát az ilyen személyek esetében.

7. A külföldiek és az állampolgárság nélküli személyek Ukrajnában az ország törvényei és/vagy Ukrajna nemzetközi szerződései alapján férhetnek hozzá az oktatáshoz.

8. A menekültté nyilvánított személy, vagy az olyan személy, akit pótlólagos oltalom illet meg Ukrajna törvénye értelmében „A menekültekről és azon személyekről, aki pótlólagos vagy ideiglenes védelemre szorulnak", ${ }^{16}$ az ukrán állampolgárokkal azonos jogokat élvez az oktatáshoz való hozzáférés területén.

9. Az oktatáshoz füződő jogot törvény nem korlátozhatja. Az oktatás bizonyos szintjének elérését, a képesítés (foglalkozás) megszerzését a törvény kötheti sajátos feltételekhez.

\section{4. cikk. Az ingyenes oktatáshoz való hozzáférés jogának biztosí- tása}

1. Az állam biztosítja:

az iskola előtti nevelés, általános középiskolai, szakképzés (szakmunkásképzés), felsőfokú szakképzés és felsőoktatás ingyenességét az oktatási standardoknak megfelelően;

iskola elötti nevelési, általános középiskolai, szakképzési (szakmunkásképzési), felsőfokú szakképzési és felsőoktatási, valamint az iskolán kívüli és a diploma utáni képzési intézmények fejlesztését a törvényeknek megfelelően.

2. Ingyenes oktatásra jogosultak:

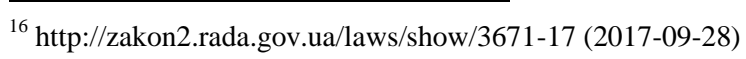

REGIO 25. évf. (2017) 3. szám 260-277. 
az iskoláskor elötti intézményekbe járók, az elemitől az érettségiig tanulók - minden oktatási intézményben tulajdonformától függetlenül, valamint biztosított ezen intézmények finanszírozása a törvényi elöírásoknak megfelelően, és olyan mértékben, ami elegendő Ukrajna minden állampolgárának, és az Ukrajna területén állandó vagy ideiglenes lakhellyel rendelkező a külföldi állampolgároknak és az állampolgárság nélküli személyeknek az oktatáshoz való hozzáférése jogának biztosítására;

az iskolán kívüli, középfokú szakmai, felsőfokú szakmai és felnőttképzésben résztvevők számára - az oktatási intézményekben vagy az oktatási tevékenység egyéb szubjektumaiban állami és/vagy helyhatósági költségvetésből a törvények által meghatározott rendben.

3. Az állam szavatolja Ukrajna minden állampolgára számára, és minden olyan személy számára, aki törvényesen tartózkodik Ukrajna területén, az ingyenes oktatást az érettségiig bezárólag az oktatási standardoknak megfelelöen.

Az állam minden tanulónak és pedagógusnak szavatolja az ingyenes tankönyvellátást (beleértve a web-tankönyveket is) az érettségiig vezető oktatási szinteken, Ukrajna Miniszteri Kabinetje ${ }^{17}$ által meghatározott rendben.

\section{5. cikk. Az állami politika az oktatási szférában}

1. Az oktatás állami prioritás, amely biztosítja a társadalom innovatív, társadalmi-gazdasági és kulturális fejlődését. Az oktatás finanszírozása befektetés a humán tőkébe, a társadalom és az állam fenntartható fejlődésébe.

2. Az oktatás területén az állam politikáját Ukrajna Legfelsőbb Tanácsa határozza meg, és Ukrajna kormánya, a végrehajtó hatalomnak az oktatás és tudomány területén tevékenykedő központi hatósága, a végrehajtó hatalom más központi szervei és a helyi önkormányzati szervek hajtanak végre.

3. Az oktatás területén az állami szakpolitikát tudományos kutatások, a nemzetközi kötelezettségvállalások, a hazai és külföldi tapasztalatok alapján alakítják ki és hajtják végre, figyelembe véve az elörejelzéseket, statisztikai adatokat és fejlesztési mutatókat az emberek és a társadalom igényeinek kielégítése céljából.

\footnotetext{
${ }^{17}$ Miniszteri Kabinet $=$ kormány.
}

REGIO 25. évf. (2017) 3. szám 260-277. 
4. Az oktatás fejlesztésének állami tervezési és stratégiai dokumentumai közé tartozik Ukrajna oktatásfejlesztési elörejelzése, oktatási stratégiája, a hatalmi szervek megfelelő állami, regionális és helyi célirányos programjai, cselekvési tervei. A hatóságok nyilvános hozzáférést biztosítanak ezekhez a dokumentumokhoz hivatalos honlapjaikon.

5. Az állam megteremti a feltételeket a polgári oktatás megszerzésére, amely azoknak a kompetenciáknak a fejlesztésére irányul, melyek a társadalom tagjaként a jogok és kötelezettségek gyakorlásához, a polgári (szabad demokratikus) társadalom értékeinek megértéséhez, a joguralomhoz, az ember és az állampolgár szabadságjogaihoz kapcsolódnak.

\section{6. cikk. Az állami politika alapjai az oktatás területén és az oktatási tevékenység elvei}

1. Az állami politika alapjai az oktatás területén és az oktatási tevékenység elvei a következők:

- emberközpontúság;

- jogállamiság;

- az oktatás minőségének és az oktatási tevékenység minőségének biztosítása;

- az oktatáshoz való egyenlő hozzáférés biztosítása mindennemü diszkrimináció nélkül, beleértve a fogyatékosok hátrányos megkülönböztetésének tilalmát is;

- inkluzív oktatási közeg biztosítása, beleértve a sajátos oktatási igényüek lakhelyéhez képest leginkább hozzáférhető és legközelebbi oktatási intézményekben;

- univerzális design és intelligens felszerelés biztosítása;

- az oktatás tudományos természete;

- az oktatás sokfélesége;

- az oktatási rendszer integritása és folytonossága;

- átláthatóság és nyilvánosság a vezetői döntések elfogadása és végrehajtása során;

- az oktatást irányító hatóságoknak és az oktatási intézményeknek, valamint az oktatási tevékenység egyéb szubjaktumainak felelőssége és elszámoltathatósága a társadalom számára;

REGIO 25. évf. (2017) 3. szám 260-277. 
- a felügyeleti funkciók intézményes szétválasztása (felügyelet) és az oktatási intézmények tevékenységének ellátása;

- integráció a munkaerőpiaccal;

- elválaszthatatlan kapcsolat a világ- és a nemzeti történelemmel, kultúrával, a nemzeti hagyományokkal;

- szabadság az oktatási típusok, formák és ütemezés megválasztásában, az oktatási intézmények és az oktatási tevékenység egyéb alanyai oktatási programjában;

- akadémiai hitelesség;

- akadémiai szabadság;

- az oktatási intézmények pénzügyi, akadémiai, személyi és szervezeti autonómiája a törvény által meghatározott keretek között;

- humanizmus;

- demokratizmus;

- az oktatás, a nevelés és a fejlödés egysége;

- patriotizmusra, az ukrán nép kulturális értékeinek tiszteletben tartására, történelmi és kulturális öröksége és hagyományai tiszleterére való nevelés;

- Ukrajna Alkotmányának és törvényeinek betartására irányuló igény kialakítása, intolerancia a megsértésükkel szemben;

- az emberi szabadságjogok iránti tisztelet kialakítása, az emberi méltóság és becsület megsértésével, a fizikai és pszichikai erőszakkal, valamint a bármilyen alapú diszkriminációval szembeni fellépés;

- az állampolgári és demokartikus kultúra kialakítása;

- az egészséges életmód iránti igény, az ökológiai kultúra és a környezettudatos hozzáállás kialakítása;

- a politikai pártok be nem avatkozása az oktatási folyamatba;

- a vallási szervezetek, egyházak be nem avatkozása az oktatási folyamatba (a jelen törvényben meghatározott esetek kivételével);

- a politikai, világnézeti és vallási kérdésekkel kapcsolatos információk sokoldalúsága és kiegyensúlyozottsága;

- állami-polgári igazgatás;

- állami-polgári partnerség;

- állami-magán partnerség;

- az élethosszig tartó tanulás elösegítése;

REGIO 25. évf. (2017) 3. szám 260-277. 
- integráció a nemzetközi oktatási és tudományos térbe;

- a korrupció és a megvesztegetés elutasítása;

- az állam által biztosított minden oktatási típushoz és formához való egyenlő hozzáférés.

2. Az oktatásnak Ukrajnában az esélyegyenlőség elvén kell alapulnia.

\section{7. cikk. Az oktatás nyelve}

1. Az oktatási folyamat nyelve az oktatási intézményekben az államnyelv.

Az állam Ukrajna minden állampolgára számára garantálja a formális oktatás elérését az államnyelven az oktatás minden szintjén (iskola előtti nevelés, általános középiskolai, szakképzés (szakmunkásképzés), felsőfokú szakképzés és felsőoktatás), valamint az iskolán kívüli és a diploma utáni képzési szinten az állami és önkormányzati oktatási intézményekben.

Az Ukrajna nemzeti kisebbségeihez tartozó személyeknek az önkormányzati oktatási intézményekben garantált a jog az államnyelv mellett az adott nemzeti kisebbség nyelvén folyó oktatáshoz az iskola előtti és az elemi iskolai szinteken. Ez a jog az államnyelv mellett az adott nemzeti kisebbség nyelvén oktató külön osztályok (csoportok) révén valósul meg, amelyek a törvényeknek megfelelően jönnek létre, és nem terjed ki az ukrán nyelven oktató osztályokra (csoportokra).

Az Ukrajna őshonos népeihez tartozó személyeknek az önkormányzati oktatási intézményekben garantált a jog az államnyelv mellett az adott őshonos nép nyelvén folyó oktatáshoz az iskola előtti és az általános középiskolai szinteken. Ez a jog az államnyelv mellett az adott őshonos nép nyelvén oktató külön osztályok (csoportok) révén realizálódik, amelyek a törvényeknek megfelelöen jönnek létre, és nem terjed ki az ukrán nyelven oktató osztályokra (csoportokra).

Az Ukrajna öshonos népeihez, nemzeti kisebbségeihez tartozó személyek számára garantált a jog az adott őshonos nép vagy nemzeti kisebbség nyelvének tanulásához az önkormányzati általános középfokú oktatási intézményekben vagy a nemzeti kulturális szövetségeken keresztül.

A hallássérült személyeknek biztosított a jog a jelnyelven való tanulásra és az ukrán jelnyelv megtanulására.

REGIO 25. évf. (2017) 3. szám 260-277. 
2. Az oktatási intézmények biztosítják az államnyelv kötelező oktatását, különösen a szakképző (szakmunkásképző), felsőfokú szakképző és felsőoktatási intézményekben, olyan mértékben, amely lehetővé teszi a szakmai tevékenység folytatását a választott szakirányban az államnyelv használatával.

Az őshonos népekhez, a nemzeti kisebbségekhez tartozó személyek, a külföldiek és a hontalanok számára megfelelő feltételeket teremtenek az államnyelv megtanulásához.

3. Az állam elősegíti a nemzetközi érintkezés nyelveinek tanulását, különösen az angol nyelvét, az állami és az önkormányzati oktatási intézményekben.

4. Az oktatási intézményekben az oktatási programnak megfelelöen egy vagy néhány tantárgy két vagy több nyelven is oktatható - államnyelven, angol nyelven, az Európai Unió más hivatalos nyelvein.

5. A hallgatók kívánsága szerint a szakképző és felsőoktatási intézmények megteremtik számukra a feltételeket az öshonos nép vagy nemzeti kisebbség nyelvének, mint tantárgynak a tanulásához.

6. Az állam elősegíti olyan oktatási intézmények létrehozását és müködését külföldön, amelyek ukrán nyelven oktatnak vagy oktatják az ukrán nyelvet.

7. A nyelvek használatának sajátosságait az oktatás különböző területein és szintjein speciális törvények határozzák meg.

\section{8. cikk. Az oktatás típusai}

1. A személy formális, nem formális és informális oktatás formájában érvényesíti az élethosszig tartó tanulás jogát. Az állam elismeri ezeket az oktatási típusokat, megteremti a feltételeket az oktatási folyamat szubjektumai fejlődéséhez, melyek megfelelő oktatási szolgáltatást nyújtanak, és ösztönzi valamennyi típusú képzettség megszerzését.

2. A formális oktatás az oktatási programok alapján folyik az állam által meghatározott oktatási szinteken, képzési ágazatokban, képesítések (szakmák) szerint, és előirányozza az oktatási standardok által elöírt oktatási eredmények elérését a megfelelő oktatási szinten és a képesítés megszerzését, melyet az állam meghatároz.

3. A nem formális oktatást, amely rendszerint oktatási programok alapján folyik, nem irányozza elő az állam által elismert oktatási

REGIO 25. évf. (2017) 3. szám 260-277. 
képesítések megszerzését az oktatási szinteken, ám szakmai és/vagy részleges oktatási képesítés megszerzésével zárulhat.

4. Az informális oktatás (önképzés) olyan képzés, amely magában foglalja bizonyos kompetenciák önszerveződő megszerzését egy személy által, különösen a szakmai, szociális vagy egyéb tevékenységekhez kapcsolódó mindennapi tevékenységekben, családi vagy szabadidős tevékenységek során.

5. A nem formális és/vagy informális oktatás során megszerzett oktatási eredmények elsimerése a formális oktatási rendszer keretében a törvények által megszabott rendben történik.

\section{9. cikk. Az oktatás megszervezésének formái}

1. A személynek joga van különböző oktatási formákban vagy azok kombinálásával hozzáférnie az oktatáshoz.

Az oktatás megszerzésének alapvető formái a következők:

intézményes (teljes (nappali és esti), levelező, távoktatás, hálózati oktatás);

egyéni (külső, családi (otthoni), pedagógiai patronálás, a munkahelyen (a termelésben);

duális.

2. A teljes (nappali, esti) oktatás az oktatás szervezésének egyik módja, amely közvetlen részvételt jelent az oktatási folyamatban.

3. A levelező az oktatás szervezésének módja, amely a teljes munkaidőben történő oktatás rövidtávú időszakait kombinálja az oktatási program önálló elsajátításával a beutazási időszakok között.

4. A távoktatás az oktatás szervezésének egyéni módja, amely elsősorban az oktatási folyamat távoli résztvevőinek közvetett interakcióján keresztül valósul meg olyan speciális környezetben, amely a modern neveléslélektani, információs és kommunikációs technológiák alapján müködik.

5. Az oktatás hálózati formája, amelyen keresztül az oktatási program megszervezésében különféle oktatási intézmények vesznek részt, amelyek szerzödéses alapon kölcsönhatásban állnak egymással.

6. A külső oktatási forma (externátus) az oktatásban résztvevők képzésének egyik módja, amely szerint az oktatási programot a hallgató egyénileg integrálja, és az oktatási eredmények kiértékelése

REGIO 25. évf. (2017) 3. szám 260-277. 
és az iskolai végzettség megszerzése a törvénynek megfelelően történik.

7. A családi (otthoni) forma az oktatási folyamat megszervezésének az a módja, amit a gyerekek szülei szerveznek meg a formális (iskola elötti, általános középiskolai) és/vagy nem formális oktatás megszerzésének céljából. A gyermekek oktatásának az állami standardok szintjénél nem alacsonyabb színvonalon történő biztosításáért a szülők felelősek. Az oktatási eredmények értékelése és az oktatási végzettségek odaítélése a jogszabályokkal összhangban történik.

8. A pedagógiai patronálás a pedagógusok által szervezett olyan oktatási forma, amelyet olyan személyeknek nyújtanak az oktatási program átadása céljából, akik pszichofizikai állapotuk következtében vagy más, a törvény által meghatározott okokból, különösen az oktatáshoz való hozzáférés biztosítása okán, erre az oktatási formára szorulnak.

9. A képzettség megszerzése a munkahelyen olyan oktatási forma, amelynek révén az oktatási program elsajátítása (rendszerint a szakoktatási, szakképzési, felsőfokú szakképzési és felsőoktatás előtti szinen) a termelésben történik gyakorlati képzés formájában, a munkavállalói kötelezettségek ellátása során gyakorló szakemberek vezetése alatt, akiket így bevonnak az oktatás és képzés folyamatába. 10. A duális oktatás az oktatás olyan formája, amely magában foglalja az oktatást, illetve a vállalkozások, intézmények és szervezetek munkafolyamatainak tanulmányozását egy bizonyos képesítés megszerzése céljából, rendszerint szerződés alapján.

11. A különféle oktatási szintek oktatási formái alkalmazásának sajátosságait speciális törvények határozhatják meg.

12. Az oktatási formákra vonatkozó rendelkezéseket az oktatást felügyelö végrehajtó hatalom központi szerve hagyja jóvá.

REGIO 25. évf. (2017) 3. szám 260-277. 


\section{RÉSZ}

\section{AZ OKTATÁS SZERKEZETE}

$[\ldots]$

\section{RÉSZ AZ OKTATÁSI INTÉZMÉNYEK}

\section{2. cikk. Az oktatási intézmények szervezési-jogi státusza}

1. A jogi személy akkor rendelkezik oktatási intézmény státusszal, ha fö tevékenységi köre az oktatási tevékenység.

Az oktatási intézmény e Törvény és Ukrajna más jogszabályai által elöírt jogai és kötelezettségei az egyénre is vonatkoznak - az oktatási tevékenységgel foglalkozó vállalkozóra, illetve természetes vagy jogi személy szervezeti egységére. A természetes személy vállalkozó, illetve jogi vagy természetes személy, akinek az oktatás kikerül az alaptevékenységei közül, elveszíti [az oktatáshoz kötődő] jogait és kötelezettségeit, köztük az oktatási intézményre vonatkozó törvény által megszabott előnyöket.

Az oktatási tevékenység akkor számít alaptevékenységnek, amennyiben az adott jogi személy (természetes személy vállalkozó) általános tevékenységéből származó bevételének több mint a fele ebböl a tevékenységfajtából származik.

2. Az oktatási intézmény mint a gazdálkodási tevékenység alanya a következő státuszokban müködhet:

költségvetési intézmény;

nonprofit oktatási intézmény;

tandíjas oktatási intézmény.

3. Az oktatási intézmény az alapítótól függően lehet állami, önkormányzati, magán vagy vállalati.

4. Az oktatási intézmény több szinten is folytathat oktatási tevékenységet, és ennek megfelelően létrehozhat szerkezeti egységeket.

5. Az oktatási intézmény az alapszabályban lefektetett tevékenységének ellátására szerződéses alapon egyesülhet más jogi személyiségekkel oktatási, oktatási-tudományos, tudományos, oktatási-termelési és egyéb intézmények létrehozása érdekében, miközben minden tag megőrzi önálló jogi személyiségét.

REGIO 25. évf. (2017) 3. szám 260-277. 
6. Az oktatási intézmény státusát, szervezeti-jogi formáját, típusát az alapító határozza meg és az rögzítésre kerül az oktatási intézmény alapító okiratában.

7. Az oktatási intézmények a tulajdonformától függetlenül azonos jogokkal és kötelezettségekkel rendelkeznek az oktatási tevékenység megvalósítása során a törvényeknek megfelelően.

8. Az oktatási intézmények saját alapító okirataik alapján müködnek, melyeket az alapítók hagynak jóvá a törvényeknek megfelelően.

\section{3. cikk. Az oktatási intézmény autonómiája}

1. Az állam szavatolja az oktatási intézmények akadémiai, szervezeti, pénzügyi és személyzeti autonómiáját.

2. Az oktatási intézmények autonómiájának mértékét e Törvény, a vonatkozó jogszabályok és az oktatási intézmény alapító okirata határozza meg.

\section{4. cikk. Az oktatási intézmény irányítása}

1. Az oktatási intézmény irányítását a törvény és az alapító okirat határozza meg.

Az intézmény alapító okiratának külön kell választania az alapító (alapítók), valamint az oktatási intézmény irányító testülete és annak szervezeti alegységei kompetenciáit a törvényeknek megfelelően.

2. Az oktatási intézmény irányítását az törvény és az intézmény alapító okiratában foglalt felhatalmazás keretei között a következők gyakorolják:

az alapító (alapítók);

az oktatási intézmény vezetője;

az oktatási intézmény kollektív vezető testülete;

az önkormányzat kollektív testülete;

egyéb szervek, amelyeket a vonatkozó törvények és/vagy az oktatási intézmény alapító okirata meghatároz.

REGIO 25. évf. (2017) 3. szám 260-277. 
[...]A törvény további, itt nem közölt fejezetei: IV. AZ OKTATÁS STANDARDJAI, AZ OKTATÁSI PROGRAMOK, KÉPESÍTÉSEK ÉS AZ OKTATÁSRÓL SZÓLÓ DOKUMENTUMOK; V. AZ OKTATÁS MINŐSÉGBIZTOSÍTÁSA; VI. AZ OKTATÁSI FOLYAMAT RÉSZTVEVÖI;VII.OKTATÁS, SZAKMAI FEJLŐDÉS ÉS A PEDAGÓGIAI ÉS TUDOMÁNYOS-OKTATÓI DOLGOZÓK MUNKABÉRE; VIII. IRÁNYÍTÁS ÉS ELLENŐRZÉS AZ OKTATÁSI SZFÉRÁBAN; IX. AZ OKTATÁSI INFRASTRUKTÚRA; X. A PÉNZÜGYIGAZDASÁGI FELTÉTELEK AZ OKTATÁSI SZFÉRÁBAN; XI.NEMZETKÖZI EGYÜTTMÜKÖDÉS; XII. ZÁRÓ ÉS ÁTMENETI RENDELKEZÉSEK.

REGIO 25. évf. (2017) 3. szám 260-277. 